\title{
Kedwibahasaan Karyawan Pariwisata Kabupaten Gianyar, Bali
}

\author{
Anak Agung Pradnya Wati ${ }^{*}$, I Wayan Simpen ${ }^{2}$, Ni Wayan Arnati ${ }^{3}$ \\ ${ }^{[123]}$ Program Studi Sastra Indonesia, Fakultas Ilmu Budaya, Universitas Udayana \\ ${ }^{1}$ [pradnyawatii18@gmail.com], ${ }^{2}$ [wyn_simpen89@gmail.com], \\ 3 [wynarnati@gmail.com] \\ *Corresponding Author
}

\begin{abstract}
This research entitled "Bilingual of Employee Tourism in Gianyar Regency, Bali". The purpose of this research is to know the bilingual of tourism employee in Gianyar based on topic, situation, aspect, and causal factor. The theory used is a sociolinguistic theory that was discovered by Mackey and Fishman. Methods and techniques of data collection used is a method refer to instrument techniques, see libat ably, and record. In the data analysis phase using qualitative and quantitative methods. In the presentation stage of data analysis using informal and formal methods. The population of this study is the entire employees engaged in tourism in Gianyar regency, Bali. The sample of this study was sixty respondents. Based on the analysis that has been done is known that employees working in the field of tourism in Gianyar mastered two to three languages. The modern topic of the language office realm that is often used is Indonesian, while for traditional topics the language is often used is the local language. For situations in the realm of the office, formal situations use the Indonesian language, whereas in informal situations often use local languages. Modern and traditional topics in the domestic realm of informal situations use local languages, namely Balinese and Javanese. However, the most widely encountered is the Balinese language. The Balinese language consists of two types, namely high and low. The high variety used by triwangsa and low variety is used by employees not triwangsa. In addition, the factors that cause bilinguality among employees are internal and external factors. Internal factors, namely age, gender, and daily life of respondents. External factors, ie speech, topic, and speaker contact. The biggest factor is the external factor.
\end{abstract}

Keyword: bilingual, tourism, employees

\begin{abstract}
Abstrak
Penelitian ini berjudul "Kedwibahasaan Karyawan Pariwisata di Kabupaten Gianyar, Bali”. Tujuan penelitian ini untuk mengetahui kedwibahasaan karyawan pariwisata di Gianyar berdasarkan topik, situasi, ranah, dan faktor penyebab. Teori yang digunakan adalah teori sosiolinguistik yang dikemukanan oleh Mackey dan Fishman. Metode dan teknik pengumpulan data yang digunakan adalah metode simak dengan teknik instrumen, simak libat cakap, dan rekam. Tahap analisis data digunakan metode kualitatif dan kuantitatif. Tahap penyajian hasil analisis data digunakan metode informal
\end{abstract}


dan formal. Populasi penelitian ini adalah keseluruhan karyawan yang bergerak di bidang pariwisata di Kabupaten Gianyar, Bali. Sampel penelitian ini enam puluh responden. Berdasarkan analisis yang telah dilakukan diketahui bahwa karyawan yang bekerja di bidang pariwisata di Gianyar menguasai dua sampai tiga bahasa. Topik modern ranah kantor bahasa yang sering digunakan adalah bahasa Indonesia, sedangkan untuk topik tradisional bahasa yang sering digunakan adalah bahasa daerah. Untuk situasi di ranah kantor, situasi formal menggunakan bahasa Indonesia, sedangkan pada situasi informal sering menggunakan bahasa daerah. Topik modern dan tradisional pada ranah rumah tangga situasi informal menggunakan bahasa daerah, yaitu bahasa Bali dan bahasa Jawa. Namun, yang paling banyak ditemuikan adalah bahasa Bali. Bahasa Bali itu terdiri atas dua ragam, yaitu tinggi dan rendah. Ragam tinggi digunakan oleh triwangsa dan ragam rendah digunakan oleh karyawan bukan triwangsa. Selain itu, faktor penyebab terjadinya kedwibahasaan di kalangan karyawan adalah faktor internal dan eksternal. Faktor internal, yaitu usia, jenis kelamin, dan keseharian diri responden. Faktor eksernal, yaitu lawan tutur, topik, dan kontak penutur. Faktor yang paling besar pengaruhnya adalah faktor eksternal.

\section{Kata kunci: kedwibahasaan, karyawan pariwisata}

\section{Latar Belakang}

Kabupaten Gianyar merupakan salah satu kabupaten yang terkenal akan seni di Bali dan memiliki banyak tempat wisata, seperti pemandangan alam, kebun binatang, pura, hotel, restoran, dan wisata budaya (water-sport-bali.com). Gerakan pemerintah khususnya pemerintah Kabupaten Gianyar dalam memfasilitasi pengunjung, antara lain dengan memberikan izin membangun penginapan, hotel, restoran, dan tempattempat wisata serta perbaikan jalan-jalan menuju tempat wisata tersebut.

Masyarakat yang bekerja di bidang pariwisata di Gianyar berasal dari berbagai latar belakang seperti halnya karyawan yang memiliki tingkatan status sosial masyarakat yang terpandang dan terdapat juga yang berasal dari luar Bali tetapi, sudah lama menetap di Gianyar. Selain dilihat dari status sosialnya, karyawan pariwisata di Gianyar juga berasal dari berbagi usia mulai dari usia 19 tahun sampai 60 tahun.

Seseorang yang bekerja di bidang pariwisata harus memiliki pengetahuan dalam penggunaan bahasa. Bahasa memiliki fungsi dan peranan yang sangat penting dalam kehidupan, yaitu sebagai alat komunikasi dan lambang tingkatan status sosial masyarakat. Bahasa yang digunakan dipengaruhi secara internal seperti kegiatan sehari-hari dalam pekerjaan. Selain itu, juga dipengaruhi secara eksternal seperti bahasa di rumah tangga yang terbawa ke lingkungan kerja. Masyarakat Bali khususnya di daerah Gianyar yang bekerja atau yang berkecimpung dalam dunia pariwisata memengaruhi tingkat penggunaan bahasanya. Oleh karena itu, penggunaan bahasa karyawan pariwisata di Gianyar layak dikaji berdasarkan kajian bahasa khususnya sosiolinguistik.

\section{Rumusan Masalah}

Berdasarkan latar belakang di atas, beberapa masalah dapat dideskripsikan dalam penelitian ini. Beberapa masalah tersebut dapat diteliti dan dikaji berdasarkan rumusan masalah sebagai berikut.

a. Bagaimanakah kedwibahasaan karyawan di lingkungan pariwisata 
Kabupaten Gianyar berdasarkan topik modern dan topik tradisional?

b. Bagaimanakah kedwibahasaan karyawan pariwisata di lingkungan Kabupaten Gianyar berdasarkan topik modern dan tradisional pada situasi formal dan informal?

c. Bagaimanakah kedwibahasaan karyawan di lingkungan pariwisata Kabupaten Gianyar di ranah kantor dan ranah rumah tangga?

d. Faktor-faktor apa sajakah yang mendasari terjadinya kedwibahasaan?

\section{Tujuan Penelitian}

Berdasarkan rumusan masalah di atas terdapat empat tujuan khusus. Adapun tujuan khusus dalam penelitian ini adalah sebagai berikut.
a. Untuk mendeskripsikan
kedwibahasaan karyawan
pariwisata Kabupaten Gianyar dalam topik modern dan topik tradisional.
b. Untuk mendeskripsikan kedwibahasaan karyawan pariwisata Kabupaten Gianyar pada situasi formal dan informal.
c. Untuk mendeskripsikan kedwibahasaan karyawan tangga. pariwisata Kabupaten Gianyar di ranah kantor dan ranah rumah
d. Untuk mengetahui faktor-faktor yang memengaruhi terjadinya kedwibahasaan di kalangan karyawan pariwisata di Kabupaten Gianyar.

\section{Metode Penelitian}

Populasi penelitian adalah keseluruhan karyawan pariwisata di Kabupaten Gianyar. Sampel yang digunakan adalah enam puluh responden. Pengumpulan data menggunakan metode simak dengan tiga teknik, yaitu teknik instrumen, teknik simak libat cakap, dan teknik rekam. Analisis data menggunakan metode kualitatif dan metode kuantitatif. Metode analisis kualitatif dilakukan secara khusus dari data yang diperoleh melalui pengamatan dan simak libat cakap pada informan. Metode kualitatif bersifat deskriptif yang bertujuan untuk menguraikan dan menjelaskan sifat atau karakteristik data karyawan yang telah diperoleh melalui kuesioner. Hasil analisis data menggunakan metode formal dan metode informal. Metode formal digunakan dalam menyajikan data statistik, yaitu untuk menghitung frekuensi pemakaian bahasa oleh karyawan yang dwibahasawan. Metode informal digunakan untuk mendeskripsikan data yang telah dihitung.

\section{Hasil Penelitian}

Pembahasan pada penelitian ini dilakukan berdasarkan hasil penelitian lapangan yang berupa kuesioner dan wawancara. Analisis penelitian ini dibagi menjadi beberapa uraian sebagai berikut.

\subsection{Pemakaian Bahasa oleh Karyawan Pariwisata di Kabupaten Gianyar pada Ranah Kantor}

Berdasarkan data yang diperoleh ditemukan jenis bahasa yang digunakan oleh karyawan di lingkungan pariwisata di Gianyar. Pemilihan dan pemakaian bahasa dalam kajian variabel situasi dibagi menjadi dua, yaitu situasi formal dan situasi informal. Selain itu, variabel pendukung yang lain adalah topik, yaitu topik modern dan topik tradisional serta hubungan keakraban antarpelibat. Berikut diuraikan hasil dan contoh setiap variabel. 


\subsubsection{Topik Modern}

Topik modern adalah pokok pembicaraan yang berkaitan dengan halhal serta tindakkan sesuai dengan tuntutan zaman. Berikut contoh dialog berdasarkan topik modern.

\section{Contoh Wacana 8}

Karyawan laki-laki : Gung aji, mawu wenten nak makte biji kopi, niki nota barangne. 'Gung aji, tadi ada orang yang mengantar biji kopi, ini notanya'

Atasan

: Be cek mare biji

kopi ne abe e?

'sudah dicek tadi

biji kopi yang dibawa?'

Karyawan laki-laki : Ampun nike gung aji, sareng Kadek tiang cek mawu 'sudah Gung Aji, sama Kadek saya mengecek tadi'

Wacana 8 di atas adalah dialog dalam situasi resmi, yaitu saat jam kerja yang dilakukan oleh karyawan Kopi Luwak Jambe dengan atasan. Bahasa yang digunakan oleh karyawan laki-laki dengan atasannya adalah bahasa Bali ragam tinggi. Pelibat dalam dialog di atas memiliki hubungan yang akrab. Hal tersebut dilihat dari panggilan satu sama lain serta bahasa yang digunakan.

\subsubsection{Topik Tradisional}

Jenis bahasa yang ditemukan pada topik tradisional, yaitu bahasa Bali (ragam tinggi-ragam rendah), bahasa Indonesia, bahasa asing, dan bahasa campur (bahasa Indonesia-bahasa Balibahasa Indonesia- bahasa asing). Berikut salah satu contoh bahasa yang digunakan oleh karyawan pariwisata di Gianyar daalam topik tradisional ranah kantor.

\section{Contoh Wacana 13}

Karyawan 1 : Besok kita semua diundang oleh Pak Beni. Besok anaknya telu bulanan 'besok anaknya tiga bulanan'

Karyawan 2 : Terus besok kan acara adatnya jam tiga, terus ada acara wayang cemblong juga. Nah sekarang siapa yang bisa dateng sorenya dan siapa yang bisa dateng malemnya?

Karyawan 3 : Rage ane peteng gen be, pang maan mebalih wayang cemblong 'Saya yang malem saja, supaya dapat nonton wayang cemblong'

Karyawan 1 : Nyen bin ne petengne? 'Terus siapa lagi yang malem?' Ane sore ajak yang, sambil ngabe kopi, gule, ajak kado 'yang sore nanti biar sama saya sambil membawa kopi, gula, dan kado'

Contoh dialog di atas merupakan contoh pemilihan bahasa dalam topik tradisional dengan pembahasan undangan tiga bulanan. Bahasa yang digunakan adalah bahasa campur, yaitu bahasa Indonesia dan bahasa Bali ragam rendah. Antarkaryawan memiliki hubungan yang akrab, dapat dilihat dari bahasa yang digunakan.

\subsubsection{Situasi Formal}

Pemilihan dan pemakaian bahasa oleh karyawan pariwisata di Kabupaten Gianyar pada situasi formal terdapat empat jenis bahasa. Bahasa-bahasa yang 
digunakan dalam situasi formal adalah bahasa Bali (ragam tinggi-ragam rendah), bahasa Indonesia, bahasa asing, dan bahasa campur (bahasa Indonesia- bahasa asing dan bahasa Bali-bahasa Indonesia). Berikut contoh hasil wawancara dengan responden dalam situasi formal.

\section{Contoh Wacana 1}

$\begin{array}{cl}\text { Atasan } & \text { : Saat ini, pertunjukan } \\ & \text { barong sudah mulai } \\ & \text { ramai kembali, untuk } \\ & \text { menarik lebih banyak } \\ & \text { pengunjung rencananya } \\ & \text { saya akan menambah } \\ & \text { tarian lepas. Bagaimana } \\ & \text { menurut kalian? } \\ \text { Karyawan : } & \text { Baik Bu, tapi di bagian } \\ & \text { mananya akan Ibu } \\ & \text { tambahkan tarian lepas? } \\ & \text { Di awal pembukaan } \\ & \text { sebelum barongnya } \\ \text { mulai atau di penutupan? } & \\ \text { : } & \text { Rencananya saya akan } \\ \text { menambah tarian lepas di } & \\ \text { akhir pertunjukan. } \\ \text { Tarian yang rencananya } \\ \text { akan saya rambah adalah } \\ \text { tari cindrawasih. Untuk } \\ \text { para penari silahkan } \\ \text { mencocokkan gerak } \\ \text { dengan musiknya. Jika } \\ \text { penari sudah siap, maka } \\ \text { kita sudah bisa } \\ \text { memasukkan tarian baru } \\ \text { ke dalam pertunjukan ... }\end{array}$

Salah satu wacana di atas adalah dialog dalam situasi resmi, yaitu saat rapat yang dilakukan oleh karyawan pertunjukan barong Jambe dengan atasan. Bahasa yang digunakan adalah bahasa Indonesia baku.

\subsubsection{Situasi Informal}

Bahasa-bahasa yang digunakan dalam situasi informal, yaitu bahasa Bali (ragam tinggi-ragam rendah), bahasa
Indonesia, bahasa asing, dan bahasa campur (bahasa Indonesia-bahasa asing dan bahasa Bali-bahasa Indonesia). Berikut salah satu contoh dialog saat responde dalam situasi informal.

\section{Contoh Wacana 4}

Karyawan $1: D i$, silih motor e motor rage e bedah ban ne 'Di pinjam motornya, motorku pecah bannya'

Karyawan 2 : Kal kije emangne? 'mau ke mana emangnya?'

Karyawan 1 : Meli nasi dauhne, kel nitip? 'Beli nasi di barat, mau beli?'

Karyawan 2 : Ae, ne pis jag kunci motore 'Iya, ni uang sama kunci motornya'

Wacana 4 merupakan contoh percakapan antarkaryawan dalam situasi informal saat jam istirahat. Bahasa yang digunakan oleh karyawan adalah bahasa Bali ragam rendah.

\subsection{Pemakaian Bahasa oleh Karyawan Pariwisata di Kabupaten Gianyar pada Ranah Rumah Tangga}

Pemilihan dan pemakaian bahasa dalam berkomunikasi di ranah keluarga tidak jauh berbeda dengan ranah kantor. Variabel-variabel pendukung menyebabkan terjadi pemilihan dan pemakaian bahasa, seperti topik, pelibat, dan situasi. Variabel topik pada penelitian ini dibagi dua, yaitu topik modern dan topik tradisional. Situasi yang digunakan dalam penelitian pada ranah rumah tangga, yaitu situasi informal. Hasil yang diperoleh saat penelitian terdapat sembilan hubungan yang cukup akrab antarkeluarga, baik antara ayah dan anak atau antarsaudara. Penyebab terjadinya hubungan yang 
kurang akrab antarkeluarga berdasarkan wawancara dengan salah seorang informan karena kesibukan di antara mereka. Berdasarkan pengamatan dan hasil penelitian, bahasa yang digunakan dalam ranah rumah tangga adalah bahasa daerah Bali-Jawa (ragam tinggi-ragam rendah), bahasa Indonesia, bahasa asing (Inggris), bahasa campur (bahasa Balibahasa Indonesia).

\subsubsection{Topik Modern}

Topik modern yang dibahas dalam penelitian ini ada lima pokok pembahasan. Berdasarkan lima pokok pembahasa berikut disajikan salah satu contoh pemilihan dan pemakaian bahasa dalam komunikasi di ranah rumah tangga.

\section{Contoh Wacana 16}

Ibu : Pak, bek sajan mayah yeh ajak listrik bulan jani 'Pak, banyak sekali bayar air dan listrik bulan ini'

Ayah : kude emangne mayah yeh ajak listrik bulan jani Buk? 'Berapa memangnya membayar air dan listrik bulan ini buk?'

Ibu : Kelung atus seket pak 'tiga ratus lima puluh ribu Pak'

Ayah : Meh, bek sajan mayah jani di, orin nae panak-panake bediken ngure yeh 'Meh, banyak sekali bayar sekarang, beri tahu anakanak agar tidak membuang-buang air'

Dialog di atas merupakan contoh dialog yang mencerminkan penggunaan bahasa dari anggota keluarga, yaitu antara ayah dan ibu. Dialog tersebut terjadi di rumah saat situasi informal. Topik yang dibahas pada dialog di atas adalah topik modern terkait dengan pengeluaran, yaitu pembayaran air di rumah. Bahasa yang digunakan merupakan bahasa Bali ragam rendah.

\subsubsection{Topik Tradisional}

Topik tradisional yang dibahas pada penelitian ini juga ada lima pokok pembahasan. Berdasarkan lima pokok pembahasa tersebut berikut disajikan salah satu contoh pemilihan dan pemakaian bahasa dalam komunikasi di ranah rumah tangga.

\section{Contoh Wacana 20}

Anak 1 : Dek, bawa turun piringnya nae!

Anak 2 : Iya Mbok nanti dulu

Anak 1 : Cepet nae! Dicari semut piringnya ni!

Anak 2 : Iya nanti!

Dialog di atas merupakan contoh penggunaan bahasa antara anak pertama dan anak kedua. Dialog tersebut terjadi di rumah. Dialog tersebut merupakan contoh percakapan antara anak 1 dan anak 2 yang sedang berkelahi (marahmarah). Pemilihan dan pemakaian bahasanya menggunakan bahasa Indonesia yang tidak baku.

\subsection{Faktor-Faktor Penyebab}

\section{Kedwibahasaan di Lingkungan}

\section{Pariwisata Kabupaten Gianyar}

Faktor-faktor penyebab terjadinya kedwibahasaan menurut Mackey dalam buku Sosiologi Bahasa (1985), yaitu faktor internal dan faktor eksternal. Berikut hasil yang ditemukan di lapangan.

\subsubsection{Faktor Internal}

Faktor internal yang diperoleh di lapangan, yaitu pemakaian bahasa seharihari oleh responden dalam kegiatan yang sederhana, seperti menghitung, menulis catatan, dan berdoa. Berdasarkan enam puluh responden yang ditemui sebanyak $85 \%$ (51) yang menggunakan bahasa 
daerah dan 15\% (9) menggunakan bahasa Indonesia. Bahasa daerah yang digunakan oleh responden ada dua jenis, yaitu bahasa Bali dan bahasa Jawa. Bahasa Bali yang digunakan oleh responden untuk pemakaian sendiri sebagian besar berupa bahasa Bali ragam rendah.

Faktor internal lain yang menyebabkan terjadinya kedwibahasaan, yaitu bakat atau kecerdasan pengguna bahasa itu sendiri. Bakat atau kecerdasan seseorang dipengaruhi oleh beberapa hal, antara lain jenis kelamin dan usia. Responden perempuan lebih menguasai dan menggerti penggunaan bahasa dalam berkumunikasi. Untuk usia responden yang berusia dua puluh lima ke bawah masih banyak mempelajari bahasa lain serta masih mudah dalam menerima bahasa-bahasa yang baru.

\subsubsection{Faktor Eksternal}

Faktor eksternal yang diperoleh di lapangan ada tiga, yaitu berdasarkan lawan bicara, berdasarkan lama dan seringnya kontak, serta tekanan. Dari enam puluh responden diketahui $80 \%$ (48) yang menggunakan bahasa Bali, 3,3\% (2) menggunakan bahasa Jawa, dan $16,7 \%$ (10) menggunakan bahasa Indonesia dalam kegiatan sehari-hari di rumah.

Penggunaan bahasa di tempat kerja oleh karyawan pariwisata di Kabupaten Gianyar berdasarkan hasil yang diperoleh terdapat tiga jenis bahasa, yaitu bahasa daerah (20\%), bahasa Indonesia $(63,4 \%)$, dan bahasa asing (16,6\%). Bahasa daerah digunakan oleh responden yang beretnis sama dengan lawan bicara. Bahasa Indonesia digunakan oleh responden saat berbicara dengan orang yang berasal dari luar Bali, tidak bisa mengunakan bahasa Bali, orang yang baru dikenal, dan responden merasa lebih nyaman jika menggunakan bahasa Indonesia di ranah kantor.

Karyawan yang menggunakan bahasa daerah, bahasa Indonesia, dan bahasa asing di ranah kantor sebagian besar dipengaruhi oleh keseringan kontak dengan lawan bicara dan lamanya kontak dalam menggunakan lebih dari satu bahasa. Selain dua hal tersebut juga dipengaruhi oleh tekanan yang di dalam responden itu sendiri. Tekanan yang dimaksud di sini seperti tekanan dalam penguasaan bahasa asing oleh responden yang berada di bidang pariwisata.

\section{Simpulan}

Kedwibahasaan karyawan di lingkungan pariwisata Kabupaten Gianyar dalam ranah kantor melibatkan empat bahasa, yaitu bahasa daerah, bahasa Indonesia, bahasa asing, dan bahasa campur (Indonesia-Bali, Indonesia-asing). Karyawan pariwisata berbicara secara keseluruhan dengan pengunjung asing dominan menggunakan bahasa Inggris. Jika identitas pengunjung diketahui, karyawan akan menggunakan bahasa sesuai dengan asal pengunjung. Untuk pengunjung domestik karyawan akan menggunakan bahasa Indonesia saat melayani pengunjung. Secara keseluruhan pemakaian dan pemilihan bahasa yang paling sering digunakan oleh karyawan pariwisata Kabupaten Gianyar pada ranah kantor adalah bahasa Indonesia $(66,7 \%)$. Posisi kedua diisi oleh bahasa Bali $(33,3 \%)$. Pada ranah rumah tangga bahasa yang digunakan, yaitu bahasa Indonesia, bahasa daerah, dan bahasa asing. Bahasa yang paling sering digunakan adalah bahasa daerah (ragam tinggi dan ragam rendah).

Faktor internal dipengaruhi oleh kegiatan sehari-hari dan bakat atau kecerdasan. Dalam kegiatan sehari-hari sebagian besar karyawan menggunakan bahasa Bali. Faktor eksternal dipengaruhi 
oleh kontak dan variabel kontak itu sendiri. Karyawan pariwisata yang awalnya tidak bisa berbahasa asing, seperti bahasa Arab, India, Prancis, dan beberapa bahasa lainnya menjadi bisa karena keseringan dalam penggunaan serta mendengar bahasa tersebut. Berdasarkan data yang diperoleh dan hasil analisis dapat dikatakan bahwa karyawan di bidang pariwisata termasuk dwibahasawan yang berdiglosia.

\section{Daftar Pustaka}

Chaedar, A. Alwasilah. 1985. Sosiologi Bahasa. Bandung: Angkasa Bandung.

https://www.water-sportbali.com/pariwisata-bali/ (diakses 23 November 2017).

Jendra, I Wayan. 2007. Sosiolinguistik Teori dan Penerapannya. Surabaya: Paramita.

Sudaryanto. 2015. Metode dan Aneka Teknik Analisis Bahasa Pengantar Penelitian Wahana Kebudayaan secara Linguistis. Yogyakarta: Duta Wacana University Press. 